\title{
Denitrification of Spent Regenerated Brine Using Molasses
}

\author{
Brigita Tepuš, ${ }^{a}$ Marjana Simonič, ${ }^{b, *}$ Aleksandra Petrovič, ${ }^{b}$ and Jasmina Filipičca \\ ${ }^{a}$ Municipal Enterprice Ptuj, Puhova 10, SI-2250 Ptuj, Slovenia \\ ${ }^{\mathrm{b}}$ Faculty of Chemistry and Chemical Engineering, University of Maribor, Smetanova 17, SI-2000 Maribor, Slovenia
}

RECEIVED SEPTEMBER 10, 2013; REVISED JANUARY 22, 2014; ACCEPTED JANUARY 30, 2014

\begin{abstract}
Spent BRINE from the regeneration of exhausted resins has to be properly treated before its disposal. The heterotrophic denitrification of regenerated brine was studied in present work. Molasses which served as a carbon source has until now not been applied during brine denitrification. The nitrate and nitrite consumptions were observed according to different ratios between total organic carbon and nitrate ( $\mathrm{TOC} / \mathrm{NO}_{3}$ ratios) and the influence of $\mathrm{NaCl}$ was studied during batch experiments. This work ascertained that molasses is a very good source of carbon, and no addition of other nutrients is necessary. The complete nitrate removal from regenerated brine could be achieved using molasses.
\end{abstract}

Keywords: nitrate, denitrification, regeneration brine, molasses, kinetics

\section{INTRODUCTION}

In drinking water treatment systems, nitrate is usually removed using ion exchange. After the regeneration of ion exchange resin, the spent brine solution has to be properly treated before its disposal. Denitrification of spent regeneration brine relies on an external carbon source as an electron donor and microorganisms which use nitrate rather than oxygen as an electron acceptor. ${ }^{1,2}$ If there is insufficient carbon in the wastewater, an external source is necessary. Various carbon sources in different amounts could be used for denitirfication processes, however, discrepancies have been reported regarding process efficiency. ${ }^{3}$ Some authors claim that better efficiencies could be achieved using acetic acid as a carbon source when compared to glucose, methanol or ethanol. ${ }^{4}$ Other have shown comparable results using acetic acid and methanol., ${ }^{5,6}$ Another group of researchers gained the best results using ethanol and methanol. ${ }^{7,8}$ Some authors have reported that ethanol has many advantages over methanol, acetic acid, and glucose. $^{9}$

A strong salt $(\mathrm{NaCl})$ solution is used to regenerate the resin resulting in the production of concentrated waste brine. Only a few species of bacteria are suitable for nitrate removal from a high salt brine solution. A haloalkaliphilic species, Halomonas campisalis, ${ }^{10-12}$ or H. denirtificans ${ }^{13}$ were isolated in order to perform denitrification using different sources of carbon, such as glicerole, lactate, acetate, while metanol and ethanol were not utilised under denitrification conditions. This research indicated that a readily biodegradable substrate is an important factor effecting denitrification rate. In the first rapid denitrification phase, a readily biodegradable substrate such as reduced sugar would be used as a carbon source, and in the second slow denitrification phase, slowly biodegradable substrates such as unhydrolyzed polysaccharide. ${ }^{14}$ Some authors claim that activated sludge from wastewater treatment plants could be used for denitification of regenerated brine with a high salt content. ${ }^{15}$

Research based on utilizing molasses as a carbon source during treating waste brine has not been described in literature so far. However, its application and effectiveness have been examined in few studies relating to the denitrification of wastewater. ${ }^{13,16}$ Molasses is potentially a good carbon source because it contains invert sugars (saccharose, glucose and fructose), raffinose, chetose, starch, dextrane (total sugar content $47-48 \%$ ), proteins and other substances (30\%), growth stimulants, and inhibitors, vitamines, and water (26\%). It contains cations, such as $\mathrm{K}^{+}, \mathrm{Ca}^{2+}, \mathrm{Mg}^{2+}, \mathrm{Na}^{+}$, and anions such as $\mathrm{Cl}^{-}, \mathrm{SO}_{4}{ }^{2-}, \mathrm{PO}_{4}{ }^{3-}, \mathrm{NO}_{3}{ }^{-}$and $\mathrm{NO}_{2}{ }^{-}$. Several metals have been determined in molasses, such as Fe, $\mathrm{Zn}, \mathrm{Mn}, \mathrm{Cu}, \mathrm{Pb}$, Se, Al, and others. ${ }^{17}$ Accordingly, it contains all those nutrients necessary for the development of microorganisms, without reqiuring external sources and consequently, the denitrification becomes

\footnotetext{
* Author to whom correspondence should be addressed. (E-mail: marjana.simonic@um.si)
} 
Table 1. The composition of the regenerated brine and molasses

\begin{tabular}{ccc}
\hline Parameter & Molasses & Regenerated brine \\
\hline $\mathrm{pH}$ & 5.66 & 9.08 \\
$\mathrm{NNO}_{3}{ }^{-} / \mathrm{mg} \mathrm{L}^{-1}$ & 69 & 1996 \\
$\mathrm{SO}_{4}{ }^{2-} / \mathrm{mg} \mathrm{L}^{-1}$ & 26 & 1220 \\
$\gamma \mathrm{Cl}^{-} / \mathrm{mg} \mathrm{L}^{-1}$ & 17 & 16800 \\
$\gamma \mathrm{TOC} / \mathrm{mg} \mathrm{L}^{-1}$ & 3007 & 460 \\
$\gamma \mathrm{TC} / \mathrm{mg} \mathrm{L}^{-1}$ & 13 & 610 \\
$\gamma \mathrm{TN} / \mathrm{mg} \mathrm{L}^{-1}$ & 131 & 425 \\
\hline
\end{tabular}

more cost effective. The optimal $\mathrm{pH}$ reported for denitrification was within the range from 7 to 9 , whilst the $\mathrm{pH}$-value of the regenerated brine was normally alkaline, because the hydrogencarbonate concentration increased during the denitrification. ${ }^{18}$ Lower or higher $\mathrm{pH}$ values resulted in the accumulation of $\mathrm{NO}_{2}, \mathrm{NO}_{2}{ }^{-}$ and $\mathrm{N}_{2} \mathrm{O} .{ }^{19}$ Most investigators agree that denitrification of nitrate to nitrite follows zero order kinetics. ${ }^{20}$ The varieties of carbon substrate as well as $\mathrm{TOC} / \mathrm{NO} 3$ ratio affect the denitri-fication rate. ${ }^{21}$

The goal of this study was to assess the stability of the denitrification process when using simultaneous heterotrophic denitrification of waste brine, and the determination of kinetic denitrification parameters. Molasses which until now has not been applied during brine denitrification, was used as the carbon source. The anoxic process was applied using acclimated municipal wastewater treatment activated sludge. The nitrogen removal was calculated using a nitrogen mass balance methodology.

\section{EXPERIMENTAL}

\section{Materials}

Lewatit mono plus M 600 nitrate selective resin is a strongly alkaline, gelular anion-exchange beads of styrene-divinylbenzene copolymer. It contains a crosslinked polystyrene matrix and quaternary amine functional group. A breakthrough point was determined at the effluent concentration of nitrate of $50 \mathrm{mg} \mathrm{L}^{-1}$. The regeneration was done using $\mathrm{NaCl}$. Molasses was obtained as a by-product from sugar beet processing.
Molasses was dark brown colored with density of $1.4 \mathrm{~g} \mathrm{~cm}^{-3}$. The chemical composition of molasses was: dry matter $78-82 \%$, sugar content $45-48 \%$, proteins $7-9 \%$ and small quantities of $\mathrm{Ca}, \mathrm{Mg}, \mathrm{K}, \mathrm{P}$ and $\mathrm{Cu}$. The composition of the regenerated brine and molasses $(\gamma=$ $10 \mathrm{~g} \mathrm{~L}^{-1}$ ) is shown in Table 1 .

Activated sludge was taken from a municipal wastewater treatment plant. It was wintertime, and salt was needed to melt the snow on the roads, resulting in increased inflow of salted water to the municipal wastewater treatment plant. Therefore, it was assumed that microorganisms from the sludge would have to be adapted for denitrification at higher salt concentrations.

\section{Batch Process}

12 batch experiments were carried out under anoxic conditions, whereby dark reactors were used in order to determine the suitability of molasses application during heterotrophic denitrification. The feed data for the first 8 reactors are presented in Table 2 . In each reactor $0.1 \mathrm{~L}$ of activated sludge, $0.1 \mathrm{~L}$ of regenerated brine, and nitrate solutions in different appropriate volumes were added (Table 2). All the reactors were filled with Millipore water to the mark of $1 \mathrm{~L}$. They were kept at a constant temperature of $20 \pm 1{ }^{\circ} \mathrm{C}$ and the solutions stirred using magnetic stirrers. $\zeta\left(\mathrm{TOC} / \mathrm{NO}_{3}\right)$ ratios were set at $5.1,4.8,4.4,4.7$ in reactors $1,2,3$ and 4 , respectively. $20 \mathrm{~g}$ of molasses was added into each reactor except for reactors 3 and 4 . In reactor 3 only $15.0 \mathrm{~g}$ of glucose was added, and in reactor 4 both molasses and glucose were added in concentrations of $10 \mathrm{~g}$ and $7.5 \mathrm{~g}$, respectively. The influence of $\zeta\left(\mathrm{TOC} / \mathrm{NO}_{3}\right)$ on the nitrate and nitrite removal was studied. In reactors $5,6,7$ and 8 , the $\zeta\left(\mathrm{TOC} / \mathrm{NO}_{3}\right)$ were set at $3.1,2.2,1.6$, and 1.3 respectively, for this purpose. The initial TOCs were set in all the reactors at approximately $6300 \mathrm{mg} \mathrm{L}^{-1}$, the mass concentrations of nitrate in reactors 5 to 8 were $2064 \mathrm{mg} \mathrm{L}^{-1}$, $2911 \mathrm{mg} \mathrm{L}^{-1}, 3928 \mathrm{mg} \mathrm{L}^{-1}$, and $4909 \mathrm{mg} \mathrm{L}^{-1}$, respectively. Additionally, $20 \mathrm{~g}$ of molasses was added into reactors 6,7 and 8 after 5 days. The $\mathrm{pH}$ value was adjusted to 7.5 in reactors 6 and 7 , and to 8.5 in reactor 8 , respectively, after one week, using 2 mol L ${ }^{-1} \mathrm{NaOH}$.

Last four experiments were performed in order to study the influence of $\mathrm{NaCl}$ on nitrogen removal. $\mathrm{NaCl}$ in concentrations $5,10,15$, and $20 \mathrm{~g} \mathrm{~L}^{-1}$, respectively,

Table 2. The reactors feed data for batch experiments

\begin{tabular}{ccccccccc}
\hline Reactor No. & 1 & 2 & 3 & 4 & 5 & 6 & 7 & 8 \\
\hline$m_{\text {molases }} / \mathrm{g} \mathrm{L}^{-1}$ & 20 & 20 & - & 10 & 20 & 20 & 20 & 20 \\
$m_{\text {glucose }} / \mathrm{g} \mathrm{L}^{-1}$ & - & - & 15 & 7.5 & - & - & - & - \\
$\mathrm{NO}_{3} / \mathrm{mg} \mathrm{L}^{-1}$ & 1200 & 1284 & 1260 & 1150 & 2064 & 2911 & 3928 & 4909 \\
$\zeta\left(\mathrm{TOC} / \mathrm{NO}_{3}\right)$ & 5.1 & 4.8 & 4.4 & 4.7 & 3.1 & 2.2 & 1.6 & 1.3 \\
\hline
\end{tabular}


were added into reactors from 9 to 12 . Other reactors feed date were the same as in reactor 2 (Table 2). Samples were taken daily. Analyses of the contents of $\mathrm{NO}_{3}{ }^{-}$, $\mathrm{NO}_{2}{ }^{-}$and $\mathrm{SO}_{4}{ }^{2-}$ ions, total organic carbon (TOC), total nitrogen $(\mathrm{TN})$, the concentration of suspended solids (SS), and $\mathrm{pH}$ were performed according to ISO standards. The samples for analyses of TOC and TN were not taken from reactors from 9 to 12 due to higher salt concentrations, which could affect the determinations of these two parameters.

The nitrate reduction reactions involve the following reduction steps from nitrate to nitrogen gas (Equation 1$):^{21}$

$$
\mathrm{NO}_{3}^{-} \rightarrow \mathrm{NO}_{2}^{-} \rightarrow \mathrm{NO} \rightarrow \mathrm{N}_{2} \mathrm{O} \rightarrow \mathrm{N}_{2}
$$

In biological nitrogen removal processes nitrate is used as electron acceptor and external source such as glucose or molasses served as electron donor. If glucose is available, following chemical reaction occur: ${ }^{22}$

$$
\begin{gathered}
5 \mathrm{C}_{6} \mathrm{H}_{12} \mathrm{O}_{6}+24 \mathrm{NO}_{3}^{-} \rightarrow \\
\rightarrow 12 \mathrm{~N}_{2}+30 \mathrm{CO}_{2}+18 \mathrm{H}_{2} \mathrm{O}+24 \mathrm{OH}^{-}
\end{gathered}
$$
tion $3:^{21}$

The denitrification rate can be expressed by Equa-

$$
\frac{\mathrm{d} \gamma_{\mathrm{N}}}{\mathrm{d} t}=q_{\mathrm{m}} \gamma_{\mathrm{SS}}
$$

where $\mathrm{d} \gamma_{\mathrm{N}} / \mathrm{d} t$ is the denitrification rate $\left(\mathrm{mg} \mathrm{L}^{-1} \mathrm{~h}^{-1}\right)$ with regard to the sum of nitrate and nitrite ions, $q_{\mathrm{m}}$ the specific denitrification rate $\left(\mathrm{mg} \mathrm{g}^{-1} \mathrm{~h}^{-1}\right)$ and $\gamma_{\mathrm{SS}}$ the suspended solid's concentration $\left(\mathrm{g} \mathrm{L}^{-1} \mathrm{~h}^{-1}\right)$. The denitrification rate is independent of nitrate ion concentration while it is a function of the suspended solids.

\section{RESULTS AND DISCUSSION}

\section{Effect of Carbon Source on Denitrification}

To test the efficiency of nitrate removal with molasses and glucose, chosen physico-chemical parameters were monitored in reactors from 1 to 4 . The results are presented in Table 3. When molasses was used as a carbon source the total nitrate and nitrite removals were achieved within 48 hours as seen form Table 3 in reactors 1 and 2 . If only glucose was used as a carbon source (reactor 3), the nitrate ions were removed within 3 days and the nitrite within 5 days which meant the slowest denitrification rate compared with other reactors. In experiment where molasses and glucose together were used as a carbon source (in the ratio of $1: 1$ ), the nitrate ions were removed within 48 hours, and the nitrite ions within 4 days, respectively. This was attributed to the fact that molasses is easily biodegradable and readily usable for denitrification. These results were in agreement with another study where applied hydrolyzed molasses was found to be more effective and economical than methanol. ${ }^{14}$ Ge et $a l .{ }^{19}$ also reported that better denitrification was achieved by a combination of glucose and molasses compared with that using glucose alone. Decreasing trends of total organic carbon (TOC) and total nitrogen (TN) concentrations were observed throughout the experiments. The share of carbon uptakes during denitification were $14 \%$ and $15.8 \%$ in reactors 1 and 2 , respectively. In reactor 4 it was $7 \%$, which is half of the shares in reactor 1 . This fact was in agreement with the mass of molasses in reactor 4 which was half of that in reactor 1. It seemed that molasses was more freely available than glucose. If molasses was used as a carbon source beside total nitrate removal, TOC decreased, therefore, again the molasses seemed to be more readily biodegradable substrate than glucose. The highest amount of nitrite formed was observed in reactor with glucose. The nitrite concentration had not decreased even after 7 days. Similarly, it was reported that the maximum nitrite accumulation was obtained if glucose was used as an external carbon source. ${ }^{19}$ It could be explained by the differences in the metabolism and electron-flow velocities amongst the different carbon sources. Different types of carbon sources could show various accumulation characteristics. The nitrite accumulation during denitrification with glucose could have been caused by Alcaligenes faecalis and it was suspected that the biomass was probably not fully acclimated to the glucose. ${ }^{19}$ Molasses proved to be the more effective than glucose, because the denitrification process was completed in less than 2 days and nitrite formation was not observed.

The initial concentrations of suspended solids (SS) in the reactors varied from $2.7 \mathrm{~g} \mathrm{~L}^{-1}$ at the beginning of the process upwards up to $4 \mathrm{~g} \mathrm{~L}^{-1}$ during the $3^{\text {rd }}$ day. The suspended solids' concentrations oscillated in all four reactors. Only slight variations in sulphate ion concentrations were observed. Both parameters did not show any effects on denitrification efficiency.

\section{The Effect of $\zeta\left(\mathrm{TOC} / \mathrm{NO}_{3}\right)$ on Denitrification}

Figure 1a shows nitrate consumption at different $\zeta\left(\mathrm{TOC} / \mathrm{NO}_{3}\right)$ for reactors $2,5,6,7$ and 8 . It can be seen that at a $\zeta\left(\mathrm{TOC} / \mathrm{NO}_{3}\right)$ of 4.8 , denitrification was completed within $24 \mathrm{~h}$, and at a lower ratio of 3.1 this time increased to within $48 \mathrm{~h}$. The majority of nitrate ions were removed within $72 \mathrm{~h}$ at a $\zeta\left(\mathrm{TOC} / \mathrm{NO}_{3}\right)$ of 2.2 , but concentration of $\mathrm{NO}_{3}$ still remained at $137 \mathrm{mg} \mathrm{L}^{-1}$. The nitrate ions were not removed totally at lower ratios of 1.6 and 1.3. The concentration significantly decreased 
Table 3. Results obtained in first four batch reactors

\begin{tabular}{|c|c|c|c|c|c|c|c|c|c|c|c|c|c|c|}
\hline Reactor No. & & 1 & & & 2 & & & & 3 & & & & 4 & \\
\hline$t / \mathrm{d}$ & 0 & 1 & 2 & 0 & 1 & 2 & 0 & 1 & 2 & 3 & 7 & 0 & 1 & 2 \\
\hline $2 \mathrm{NO}_{3} / \mathrm{mg} \mathrm{L}^{-1}$ & 1199 & 1.3 & 0 & 1284 & 0.8 & 0 & 1259 & 674 & 9.7 & 0 & 0 & 1152 & 0.8 & 0 \\
\hline$\gamma \mathrm{NO}_{2} / \mathrm{mg} \mathrm{L}^{-1}$ & 63 & 285 & 0 & 40 & 147 & 0 & 21 & 198 & 358 & 154 & 33 & 77 & 215 & 0 \\
\hline $2 \mathrm{SO}_{4} / \mathrm{mg} \mathrm{L}^{-1}$ & 235 & 222 & 229 & 223 & 233 & 196 & 180 & 141 & 120 & 102 & 51 & 193 & 174 & 189 \\
\hline$\gamma \mathrm{TOC} / \mathrm{mg} \mathrm{L}^{-1}$ & 6101 & 5127 & 5244 & 6180 & 5450 & 5206 & 5482 & 5195 & 5134 & 4937 & 4654 & 5465 & 5064 & 4986 \\
\hline$\gamma \mathrm{TN} / \mathrm{mg} \mathrm{L}^{-1}$ & 540 & 342 & 294 & 533 & 320 & 288 & 233 & 171 & 104 & 56 & 17 & 347 & 178 & 139 \\
\hline $2 \mathrm{SS} / \mathrm{g} \mathrm{L}^{-1}$ & 3.0 & 3.6 & 3.3 & 2.8 & 3.1 & 3.3 & 2.7 & 3 & 2.6 & 1 & / & 2.8 & 4.3 & 3.2 \\
\hline$\zeta\left(\mathrm{TOC} / \mathrm{NO}_{3}\right)$ & 5.1 & / & l & 4.8 & / & / & 4.4 & / & l & / & l & 4.7 & I & 1 \\
\hline
\end{tabular}

over the $72 \mathrm{~h}$ but over the next $48 \mathrm{~h}$ it remained unchanged. The reason could have been an insufficient carbon source, therefore, $20 \mathrm{~g}$ of molasses was added into reactors 6,7 and 8 . This is denoted as a vertical line at day 5 in Figure 1a. The $\mathrm{pH}$ values for all reactors slowly decreased. Denitrification could be incomplete at effluent $\mathrm{pHs}$ below 6 , therefore on day 5 the $\mathrm{pH}$ values were adjusted to 7.5 in reactors 6 and 7 , and to 8.5 in reactor 8 (denoted as a vertical line at day 7), respectively. However, improved conditions by adding molasses and the adjusting of $\mathrm{pH}$ values did not enhance the denitrification process, although higher efficiencies have been reported for halophilic communities at higher pH values. ${ }^{10}$

Figure $1 \mathrm{~b}$ shows the nitrite formations and consumptions for reactors 2 , and from 5 to 8 . Initially the concentrations of nitrite ions increased at all $\zeta\left(\mathrm{TOC} / \mathrm{NO}_{3}\right)$, whilst the $\mathrm{pH}$ values decreased. The nitrites were completely removed only in reactors 2 and 5. The higest nitirite concentrations at approximately $1000 \mathrm{mg} \mathrm{L}^{-1}$ were formed in reactors 6,7 and 8 with low $\zeta\left(\mathrm{TOC} / \mathrm{NO}_{3}\right)$. In these reactors molasses was added to the solutions on the 5th day, and the pHs were adjusted on the $7^{\text {th }}$ day. However, the nitrite and nitrate consumptions could not be enhanced which could be explained by low $\zeta\left(\mathrm{TOC} / \mathrm{NO}_{3}\right)$. Due to insufficient

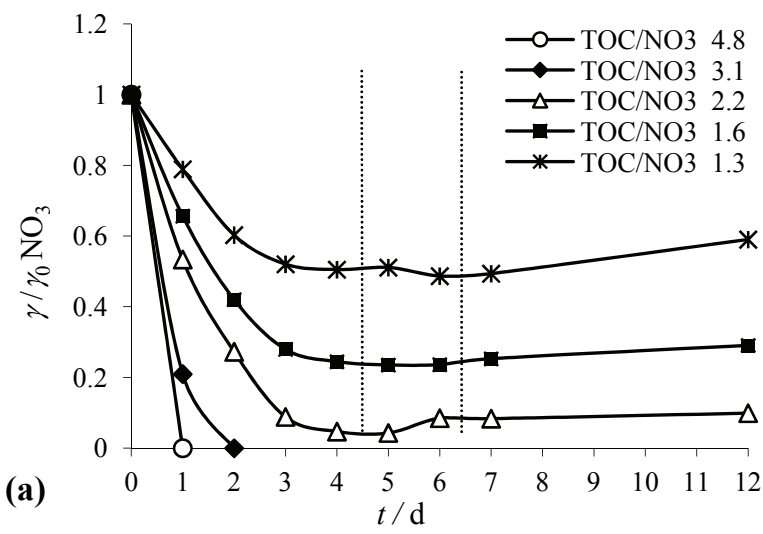

carbon supply the nitrite accumulated. The results showed that the $\zeta\left(\mathrm{TOC} / \mathrm{NO}_{3}\right)$ should be around 3.1 which is in accordance with the reported ${ }^{1} \zeta\left(\mathrm{TOC} / \mathrm{NO}_{3}\right)$ value equal to 2.7 . Lower $\zeta\left(\mathrm{TOC} / \mathrm{NO}_{3}\right)$ had negative impact on denitrification and nitrate could not be removed completely.

The initial TOC concentration (total, not filtered) was approximately $6300 \mathrm{mg} \mathrm{L}^{-1}$ in all the reactors and it slowly decreased throughout the experiment. The consumption of TOC was lower at lower $\zeta\left(\mathrm{TOC} / \mathrm{NO}_{3}\right)$. Figure 2 presents the decrease in total nitrogen. The concentration of total nitrogen decreased in accordance with decreased nitrate concentration, whilst maximum reduction was observed in those reactors with higher $\zeta\left(\mathrm{TOC} / \mathrm{NO}_{3}\right)$.

\section{The Effect of Salt on Denitrification}

Tables 4 and 5 shows the $\mathrm{NaCl}$ effect on denitrification process. No inhibitory influence of $\mathrm{NaCl}$ was observed at $5 \mathrm{~g} \mathrm{~L}^{-1}$. Nitrates and nitrites were found in the reactors, even after 7 days if the concentration of $\mathrm{NaCl}$ was above $10 \mathrm{~g} \mathrm{~L}^{-1}$. The concentration of nitrate at the end of experiment increased due to salt inhibition and partly due to biomass starvation. The experiments also showed the inhibitive effects of $\mathrm{NaCl}$ on sulphate consumption.

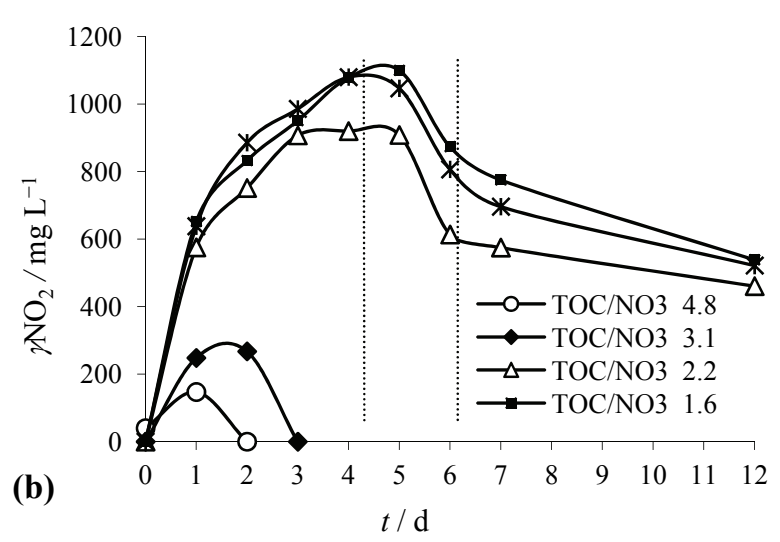

Figure 1. (a) Nitrate and (b) nitrite removal in batch experiments. 


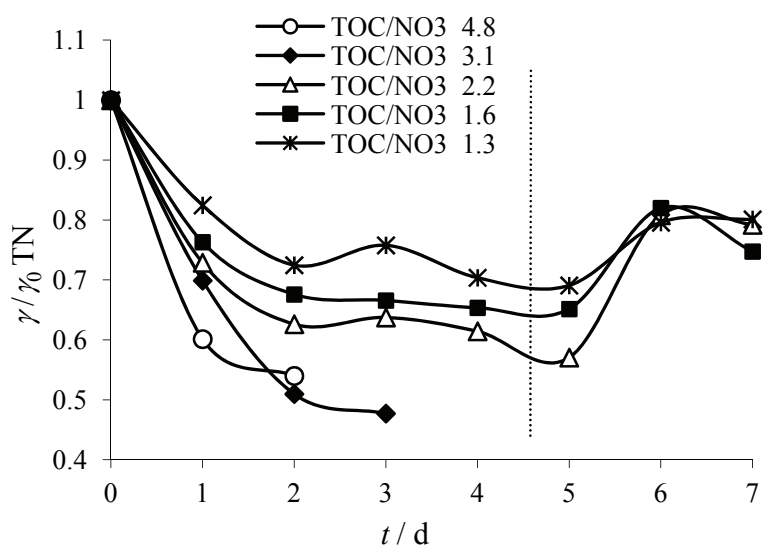

Figure 2. The content of total nitrogen in batch experiments at different $\mathrm{TOC} / \mathrm{NO}_{3}$ ratios.

The values of $\mathrm{pH}$ in all the reactors slowly decreased during the experiment, similar as in reactors from 5 to 8 (Figure 3). The results showed that denitrification in the batch experiments was successful at initial nitrate concentrations below $2000 \mathrm{mg} \mathrm{L}^{-1}$, and at the concentrations of $\mathrm{NaCl}$ up to $5 \mathrm{~g} \mathrm{~L}^{-1}$. At $10 \mathrm{~g} \mathrm{~L}^{-1}$ of $\mathrm{NaCl}$ significant amounts of nitrite were observed in the solutions and at the end of experiments some of nitrite still remained $\left(52 \mathrm{mg} \mathrm{L}^{-1}\right)$.

The results also showed that $\mathrm{NaCl}$ inhibits both denitrification steps, the reduction of nitrate to nitrite, and to a greater extent nitrite to nitrogen. The reason could be high osmotic pressure of the brines that could lead to cell death as a consequence of dehydration. ${ }^{13}$

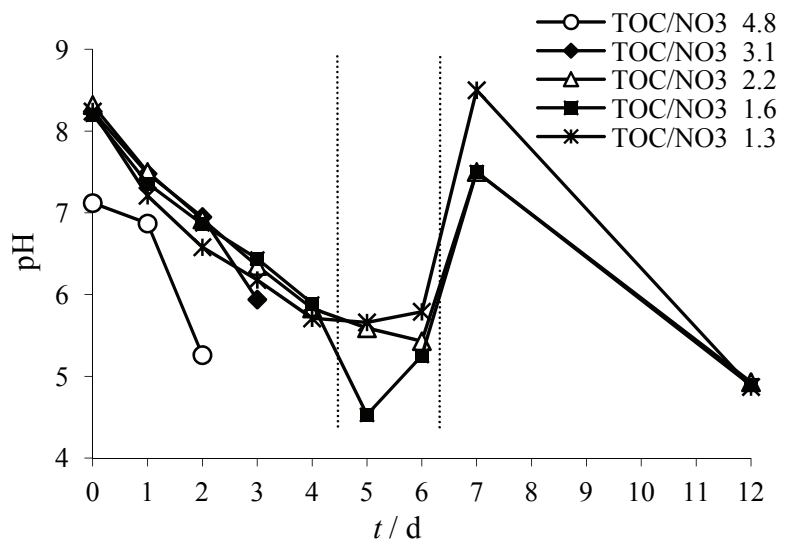

Figure 3. $\mathrm{pH}$ values in batch experiments at different $\mathrm{TOC} /$ $\mathrm{NO}_{3}$ ratios.

\section{The Specific Denitrification Rate Calculation}

The specific denitrification rate $q_{\mathrm{m}}$ (denitrification constant) was calculated according to Equation (3). The calculations for batch experiments are collected in Table 6. The denitrification rates varied between 0.16 and $25.4 \times 10^{-2}\left(\mathrm{mg} \mathrm{g}^{-1} \mathrm{~h}^{-1}\right)$. The highest denitrification rate $\left(0.254 \mathrm{mg} \mathrm{g}^{-1} \mathrm{~h}^{-1}\right)$ was achieved during batch trials with molasses used as a carbon source at $\zeta\left(\mathrm{TOC} / \mathrm{NO}_{3}\right)$ of 3.1 in reactor 5. Glucose, in comparison with the molasses, provided lower specific denitrification rates (reactors 2 and 3). In general, with any decrease in $\zeta\left(\mathrm{TOC} / \mathrm{NO}_{3}\right)$ the concentration of nitrate ions increased, and therefore the specific denitrification rate subsequently decreased. The specific denitrification rates for reactors 9 to 12

Table 4. Nitrate consumption in reactors 9 and 10

\begin{tabular}{ccccccccc}
\hline Reactor No. & \multicolumn{3}{c}{$9\left(\chi(\mathrm{NaCl})=5 \mathrm{~g} \mathrm{~L}^{-1}\right)$} & \multicolumn{2}{c}{$\left.10 \chi(\mathrm{NaCl})=10 \mathrm{~g} \mathrm{~L}^{-1}\right)$} \\
\hline$t / \mathrm{d}$ & 0 & 1 & 2 & 0 & 1 & 2 & 3 & 7 \\
$\mathrm{pH}$ & 7.12 & 7.07 & 5.77 & 7.12 & 6.78 & 5.17 & 4.9 & 4.87 \\
$\gamma \mathrm{NO}_{3} / \mathrm{mg} \mathrm{L}^{-1}$ & 1000 & 323 & 0 & 1000 & 430 & 4.3 & 7.6 & 48 \\
$\mathrm{NO}_{2} / \mathrm{mg} \mathrm{L}^{-1}$ & 0 & 249 & 0 & 0 & 225 & 150 & 121 & 52 \\
$\mathrm{SO}_{4} / \mathrm{mg} \mathrm{L}^{-1}$ & 94 & 92 & $/$ & 94 & 95 & 85 & 84 & 94 \\
$\gamma \mathrm{SS} / \mathrm{g} \mathrm{L}^{-1}$ & 2.8 & 2.9 & 5.6 & 2.8 & 3.8 & 5.7 & 9.7 & $/$ \\
\hline
\end{tabular}

Table5. Nitrate consumption in reactors 11 and 12

\begin{tabular}{ccccccccccc}
\hline Reactor No. & \multicolumn{1}{c}{$11\left(\chi(\mathrm{NaCl})=15 \mathrm{~g} \mathrm{~L}^{-1}\right)$} & \multicolumn{5}{c}{$\left.12 \chi(\mathrm{NaCl})=20 \mathrm{~g} \mathrm{~L}^{-1}\right)$} \\
\hline$t / \mathrm{d}$ & 0 & 1 & 2 & 3 & 7 & 0 & 1 & 2 & 3 & 7 \\
$\mathrm{pH}$ & 7.12 & 6.88 & 5.61 & 5.04 & 4.79 & 7.12 & 6.71 & 5.99 & 5.36 & 4.79 \\
$\mathrm{NO}_{3} / \mathrm{mg} \mathrm{L}^{-1}$ & 1000 & 517 & 6.1 & 5.6 & 57 & 1000 & 641 & 116 & 67 & 113 \\
$\mathrm{NO}_{2} / \mathrm{mg} \mathrm{L}^{-1}$ & 0 & 211 & 309 & 267 & 199 & 0 & 158 & 386 & 436 & 374 \\
$\mathrm{SO}_{4} / \mathrm{mg} \mathrm{L}^{-1}$ & 94 & 94 & 86 & 83 & 99 & 94 & 96 & 100 & 91 & 102 \\
$\gamma \mathrm{SS} / \mathrm{g} \mathrm{L}^{-1}$ & 2.8 & 4.6 & 8.6 & 6.8 & $/$ & 2.8 & 4.3 & 8.0 & 7.5 & $/$ \\
\hline
\end{tabular}


Table 6. The denitrification constants $\left(q_{\mathrm{m}}\right)$ at batch trials

\begin{tabular}{cccc}
\hline$t / \mathrm{d}$ & 1 & 2 & 3 \\
$\zeta\left(\mathrm{TOC} / \mathrm{NO}_{3}\right)$ & & $q_{\mathrm{m}} / 10^{-2}\left(\mathrm{mg} \mathrm{g}^{-1} \mathrm{~h}^{-1}\right)$ & \\
\hline 5.1 & 16.7 & $/$ & $/$ \\
4.8 & 24.7 & $/$ & $/$ \\
4.4 & 7.8 & 11.6 & 6.2 \\
4.7 & 15.0 & $/$ & $/$ \\
3.1 & 25.4 & 5.1 & 3.5 \\
2.2 & 11.7 & 6.4 & 2.8 \\
1.6 & 7.8 & 9.2 & 3.4 \\
1.3 & 3.5 & 6.1 & 2.5 \\
4.8 & 8.0 & 7.9 & $/$ \\
4.8 & 4.7 & 6.2 & 0.25 \\
4.8 & 2.9 & 3.0 & 0.56 \\
4.8 & 2.3 & 1.8 & 0.16 \\
\hline
\end{tabular}

decreased if the concentration of $\mathrm{NaCl}$ increased. Even an amount of $5 \mathrm{~g} \mathrm{~L}^{-1} \mathrm{NaCl}$ could significantly inhibit the process of the denitrification and thus the specific denitrification rate decreased. The denitrification rate of approximately $0.87 \mathrm{mg} \mathrm{g}^{-1} \mathrm{~h}^{-1}$ was reported in sequential batch reactor treating sewage using molassses as the carbon source. ${ }^{16}$ Stated value of denitrification rate is fairly comparable with the results from present research (Table 6).

\section{CONCLUSION}

The results achieved demonstrated that the denitrification process using molasses as carbon source was efficient. The kinetic parameters data obtained can be

considered as a useful tool for process design, and the operation of regeneration brine treatment. The TOC/NO $/ \mathrm{NO}_{3}$ ratio must be around 3.1 to allow heterotrophic denitrifiers to perform denitrification of regeneration brine. The sulphate and suspended solids' concentrations did not influence the denitrification rate. Total nitrate removal was achieved in 24 hours at initial concentrations of $\mathrm{NO}_{3}$ and $\mathrm{NaCl}$ up to $1 \mathrm{~g} \mathrm{~L}^{-1}$ and $5 \mathrm{~g} \mathrm{~L}^{-1}$, respectively. At $10 \mathrm{~g} \mathrm{~L}^{-1} \mathrm{NaCl}$ only partial denitrification accomplished in seven days is feasible, whilst the concentration of nitrite accumulates.

\section{REFERENCES}

1. D. A. Clifford and X. Liu, Water Res. 27 (9) (1993) 1477-1484.

2. E. J. McAdam and S. J. Judd, Sep. Purif. Technol. 62 (2008) 264-272.

3. H. Chonstatin and M. Fick, Water Res. 31 (1997) 583-590.

4. M. Henze, P. Harremoës, J. C. Jansen, and E. Arvin, Wastewater treatment: biological and chemical processes, $3^{\text {rd }}$ ed., Springer, Berlin, Germany, 2002.

5. U. Nyger, H. Aspergren, B. Andersson, J. Jansen, and I. S. Villadsen, Water Sci. Tehnol. 26 (1992) 1077-1086.

6. S. Lee, B. Koopman, S. Park, and K. Cadee, Water Environ. Res. 67 (1995) 1119-1122.

7. M. Christensson, E. Lie, and T. Welander, Water Sci. Technol. 30 (1994) 83-90.

8. B. Andersson, H. Aspergren, U. Nyberg, and H. Odegaard, Water Sci. Technol. 37 (1998) 175-183.

9. G. Cao, O. Zhao, X. Sun, and T. Zhang, Enzyme Microb. Tech. 30 (2002) 49-55.

10. B. M. Peyton, M. R. Mormile, and J. N. Petersen, Water Res. 35 (17) (2001) 4237-4242.

11. A. A. Shapovalova, T. V. Khijniak, T. P. Tourova, G. Muyzer, and D. Y. Sorokin, Extremophiles 12(5) (2008) 619-625.

12. E. J. McAdam, M. Pawlett, and S. J. Judd, Water Res. 44 (2010) 69-76.

13. P. Cyplik, W. Grajek, R. Marecik, P. Króliczak, and R. Dembczyński, Desalination. 207 (2007) 134-143.

14. Z. X. Quan, Y. S. Jin, C. R. Yin, J. J. Lee, and S. T. Lee, Bioresour. Technol. 96 (2005) 1690-1695.

15. B. U. Bae, C. H. Kim, and Y. I. Kim, Water Sci. Technol. 49 (2004) 413-419.

16. M. F. Rodriguez, F.G. de Giner, A. A Rodriguez, and E. J. Lomas, Bioresour. Technol. 88 (2003) 215-219.

17. P. W. Van der Poel, H. Schiweck, and T. Schwartz, Sugar Technology, Beet and cane sugar manufacture, Verlag Dr. Albert Bartens KG, Berlin, Germany, 1998.

18. Y. Tang, C. Zhou, E. M. Ziv, and B. E. Rittmann, Water Res. 45 (2011) 232-240.

19. S. Ge, Y. Peng, S. Wang, C. Lu, X. Cao, and Y. Zhu, Bioresour. Technol. 114 (2012) 137-143.

20. A. Carruci, R. Ramadori, S. Rossetti, and M. C. Tomei, Water Res. 30 (1996) 51-56.

21. G. Tchobanoglous, L. B. Franklin, and H. D. Stensel, Wastewater engineering treatment and reuse, Metcalf \& Eddy, $4^{\text {th }}$ Ed., McGraw-Hill Higher education, 2003, Chapter 7 and 11.

22. S. Saggar, N. Jha, J. Deslippe, N. S. Bolan, J. Luo, D. L. Giltrap, D. - G. Kim, M. Zaman, and R. W. Tillman, Sci. Total Environ. 465 (2013) 173-195. 